\title{
Shanghai Pilot Free Trade Zone and Its Effect on Economic Growth: A Counter-Factual Approach*
}

\author{
Dechun Huang, Vu Thi Van\#, Md. Ekram Hossain, Zhengqi He \\ Business School, Hohai University, Jiangning, China \\ Email: "vuvan1690@gmail.com
}

How to cite this paper: Huang, D.C., Van, V.T., Hossain, Md.E. and He, Z.Q. (2017) Shanghai Pilot Free Trade Zone and Its Effect on Economic Growth: A Counter-Factual Approach. Open Journal of Social Sciences, 5, 73-91.

https://doi.org/10.4236/jss.2017.59006

Received: August 1, 2017

Accepted: September 3, 2017

Published: September 6, 2017

Copyright $\odot 2017$ by authors and Scientific Research Publishing Inc. This work is licensed under the Creative Commons Attribution International License (CC BY 4.0).

http://creativecommons.org/licenses/by/4.0/

\begin{abstract}
Together with the deepening of globalization and economic integration, trade and investment liberalization has played more important role in economic cooperation. Besides the free trade agreements among member countries, free trade zone is also considered to establish a favorable environment in order to attract foreign investment and promote economic growth of the areas laying inside and outside the zone. On the basis of economic reforming and trade liberalization initiative, China approved the establishment of Shanghai Pilot free trade zone on September 29th, 2013. The Shanghai Pilot free trade zone is the experiment area of the whole country's national economic transition process. For the first time, many new policies and management mode were adopted in this area to examine their performance and usability. This study aims to analyze the policy's effect of Shanghai pilot free trade zone on Shanghai economic growth. By using counter-factual method, the study compares the difference of Shanghai GDP in counter-factual scenario from the actual scenario and figures out the policy effect with the existence of the free trade zone. Therefore, the finding emphasizes the strong effect of Shanghai free trade zone on its economic growth. Understanding the economic effect of Shanghai pilot free trade zone is necessary to further up investment and trade liberalization in China.
\end{abstract}

\section{Keywords}

Shanghai Pilot Free Trade Zone, Policy's Effects, Economic Growth, Counter-Factual Analysis

*Jiangsu Research Planning Project for Philosophy and Social Science: Study on Strengthening Connection Cooperation with Shanghai Free Trade Zone of Jiangsu Province (14ZB028). 


\section{Introduction}

\subsection{New Free Trade Zones in China}

The Shanghai Pilot Free Trade Zone (or the "FTZ") is located in the Pudong New Area of Shanghai, is the first free trade zone in Chinese mainland. The Shanghai FTZ was approved by China's State Council on 22 August 2013 and was officially launched on 29 September 2013. The Shanghai FTZ covers an area of 28.78 square kilometer and comprises the four existing customs supervisory zones, including Waigaoqiao Bonded Zone, Waigaoqiao Bonded Logistic park, Yangshan Bonded Port and Pudong Airport Comprehensive Bonded Zone. In 2014, it was expanded by incorporating Lujiazui Financial Area, Jinqiao Export Processing Zone, and Zhangjiang High Tech Park, expanding the area of the Free Trade Zone from 28.78 square kilometers to 120.72 square kilometer. The FTZ is expected to facilitate open trade anchored in liberalized provisions on foreign exchange management, tax policies, and customs supervision [1].

The establishment of the Shanghai FTZ, as part of the national strategy of more proactively opening up China, is a big step forward in the country's desire to adapt to new global economic trends and trade developments. The Shanghai FTZ implemented various reforms in term of policies and logistics to facilitate the free movement of goods at the regional level. With the implementation of regulatory procedures simplification, business costs reduction and large tariff-free zone, the Shanghai FTZ aimed to further open up the service industry, provide a flexible environment for foreign exchange and off-shore financial services, dramatically reduce the transaction costs of firms, and ease other regulations. The Shanghai FTZ adopted "frontline, completely liberalized" processes and reform the current practice of declaring goods before these enter the trade area as well as reduce the trading barrier with favor tariff policy and convenient administrative procedures. One highlight of the Shanghai FTZ is the adaption of the negative list system in investment management. This list includes specific projects what are not open to foreign investment or are of restricted access, otherwise are fully open to foreign investment. It is expected that Shanghai FTZ will not only encourage foreign investment investing to provide a wide range of value-added services but will also make ports as centers of commodity flow, capital flow, and information flow.

Taking shanghai free trade zone as policy reform experimental site, the State Council decided on December 28, 2014 to introduce the practices of Shanghai FTZ nationwide and later on, in April, 2015, there were three new Free Trade Zones were opened in Guangdong, Tianjin and Fujian that shared many of the features with the Shanghai FTZ, for example: the same negative list, the same registration procedure and many other common features [2]. After that, the Minister of Commerce for China continues to duplicate the Shanghai FTZ at more widespread level in different provinces. On the 31st of March, 2017, seven new FTZs were officially approved in Liaoning, Zhejiang, Henan, Hubei, Chongqing, Sichuan and Shaanxi municipality. Each FTZ not only shares many common 
features with the previous Shanghai FTZ but also has different priorities. For example, Zhejiang's FTZ will focus on international maritime services and international oil storage, while Liaoning will focus on deepening state firm reform, Chongqing's FTZ will target to develop China's “One Belt, One Road” initiative and Henan will focus on international logistics and transportation [3].

\subsection{Current Situation of Shanghai Pilot Free Trade Zone}

The Shanghai free trade pilot zone has been established for almost 4 years and continuously completes its institutional innovation by carrying out the negative list management mode for market access, deepening foreign investment, overseas investment management and commercial system reform. At the end of 2016, there are 61 "centralized registration offices" have been set up; there are 21,400 enterprises have registered in the Zone. The procedure of registration was also simplified through launching online booking, preregistration services and trial mobile phone APP for "handheld appointment." The registration time was shortened by $2 / 3$. At the end of 2016 , there were totally 79,669 enterprises operating inside the Zone, including 62,365 domestic funded enterprises, involving registered capital of 4140.362 billion yuan and 17,304 foreign-funded enterprises, involving registered capital of 243.686 billion US dollars.

In order to deepen trade facilitation, Shanghai FTZ promotes the customs clearance reform namely "three interdependence", including information exchange, supervision mutual recognition and law enforcement mutual assistance as well as introduce a trial customs clearance integration system, namely "three automations one concentration" that refer to automatic tax declaration, automatic customs clearance, automatic audit and concentrative inspection. There were 5155 customs debentures were made in 2016, in value of 6983 billion yuan, contributing 1204 billion yuan taxation with a year-on-year growth of 7.5 times, 3.0 times and 3.1 times respectively. In 2016, the total import and export trading volume was 783.68 billion yuan, rising by $5.9 \%$, of which the export volume was 231.585 billion yuan, rising by $14.5 \%$ in comparison with last year (see Table 1 ).

On financial aspect, the financial system innovation framework was basically formed with the opening of Shanghai Insurance Exchange, Shanghai Stock Exchange, China Trust Registration Co., Ltd. and the expanding of qualified companies on international wholesale trading platform. At the end of 2016, the scale of RMB cross-border transactions continuously expanded the total cross border RMB settlement hit 1151.8 billion yuan, total revenue of cross-border bilateral RMB capital pool was 352.213 billion yuan.

Regarding supervision and management, the FTZ promoted the implementation of middle and later supervision platform on both area and municipal level, opened up enterprise credit information publicity system, formed the in-the event and after-the event regulatory system for the core purpose of government function transformation.

With the development of Shanghai FTZ and the expanding of free trade zone 
Table 1. The main economic indicators of Shanghai pilot FTZ in 2016.

\begin{tabular}{|c|c|c|c|}
\hline Indicator & Unit & Value & $\begin{array}{l}\text { Year-on year } \\
\text { Growth rate }\end{array}$ \\
\hline Local general public budget revenue & 100 million yuan & 559.38 & 23.7 \\
\hline Actual capital of FDI & 100 million USD & 61.79 & 28.2 \\
\hline total industrial output value & 100 million yuan & 4312.84 & 14.2 \\
\hline $\begin{array}{l}\text { total retailing of social } \\
\text { consuming goods }\end{array}$ & 100 million yuan & 1396.76 & 6.9 \\
\hline Total merchandise sales & 100 million yuan & $33,609.23$ & 6.9 \\
\hline Operating income of services & 100 million yuan & 4167.59 & 7.0 \\
\hline Total import and export volume & 100 million yuan & 7836.8 & 5.9 \\
\hline Export volume & 100 million yuan & 2315.85 & 14.5 \\
\hline $\begin{array}{c}\text { The number of financial institutions } \\
\text { at the end of period }\end{array}$ & Number & 815 & 7.5 \\
\hline $\begin{array}{c}\text { The number of emerging financial } \\
\text { institutions }\end{array}$ & Number & 4651 & 11.9 \\
\hline
\end{tabular}

Source: Derived from Shanghai national economic and social development statistical bulletin 2016 (Shanghai Statistic Bureau: http://www.stats-sh.gov.cn/).

creation on national level in China, this paper aims to analyze the effect of the first Chinese Shanghai FTZ on its economic growth with an empirical view. As FTZ is becoming a nationwide phenomenon in China, understanding the effect and experience of Shanghai FTZ will be beneficial for implementing policy and economic reform in the new FTZs and China. The establishment of Shanghai pilot free trade zones represents China's major move to adopt a more proactive strategy of opening up in line with the new trend of global economic development.

\section{Literature Review on Free Trade Zone}

\subsection{Conceptual Issues}

The first modern economic zones (EPZs) were established in the 1960s, for example the Shannon Free Zone in Ireland in 1959, the Kandla Free Zone in India in about 1960 or the Kaohsiung Export Processing Zone in Taiwan which started in 1967, as a result of the relocation of industrial production between developed countries (DCs) and from developed countries into less developed countries (LDCs). Since then, various types of modern free zone have evolved under the special economic zone (SEZ) concept with different names, such as Free trade zone, Export processing zone, Free port and special zone... SEZs are generally defined as geographically delimited areas administered by a single body, offering certain incentives (generally duty-free importing and streamlined customs procedures, for instance) to businesses which physically locate within the zone (FIAS, 2008) [4]. Special economic zones represent designated geographical areas within an economy, where business activity is subject to different rules 
from those prevailing in the rest of the economy. Those rules can pertain to investment conditions, trade, customs and taxes, etc. [5]. In fact, there is no single and unified classification of SEZ, but this paper following the World Bank's classification and Farole [5] which classified SEZ into six types of zone with different development objectives. The comparison of six types of special economic zone is described in Table 2.

Free trade zones (FTZs; also known as commercial free zones) are fenced-in, duty-free areas, offering warehousing, storage, and distribution facilities for trade, transshipment, and re-export operations [4]. Grubel defined Free trade zones as "areas separated from the surrounding host country's territory by fences or other barriers into which goods from abroad can be brought without quota restrictions or the payment of tariffs and excise taxes, and without being subjected to exchange controls, and to the majority of statistical reporting requirements and regulations aimed at the protection of consumers" [6]. Inside free trade zone, the goods can be stored, used in manufacture, exhibited, assembled, sorted and sold and can be exported as freely as they are imported. However, if it they are brought into the zone's host country, they are dominated by the normal import quotas, duties and excise taxes.

If free trade zones are designed to accelerate trading, Export processing zones (EPZ) has the sole aim to produce goods for exporting purpose. EPZs are industrial clusters offering incentives and facilitation of manufacturing and other activities prevalently export-oriented. The manufacturing units are given tax holiday for a fixed period of time so as to make the product competitive in the international market. Hybrid EPZs are typically sub-divided into a general zone open to all industries and a separate EPZ area reserved for export-oriented, EPZ-registered enterprises while single factory EPZ aim to provide incentives to

Table 2. Classification of SEZ.

\begin{tabular}{|c|c|c|c|c|}
\hline Type of zone & $\begin{array}{l}\text { Development } \\
\text { objectives }\end{array}$ & Typical size & $\begin{array}{l}\text { Typical } \\
\text { Activities }\end{array}$ & Markets \\
\hline $\begin{array}{l}\text { Free trade } \\
\quad \text { zone }\end{array}$ & Support trade & $<50$ hectares & $\begin{array}{l}\text { Entrepôts and } \\
\text { trade-related }\end{array}$ & Domestic, re-export \\
\hline $\begin{array}{c}\text { Export } \\
\text { processing } \\
\text { zones }\end{array}$ & $\begin{array}{c}\text { Export \& } \\
\text { manufacturing }\end{array}$ & $<50$ hectares & $\begin{array}{l}\text { Manufacturing } \\
\text { and processing }\end{array}$ & Mostly export \\
\hline Hybrid EPZs & $\begin{array}{c}\text { Export \& } \\
\text { manufacturing }\end{array}$ & $<100$ hectares & $\begin{array}{l}\text { Manufacturing } \\
\text { and processing }\end{array}$ & $\begin{array}{l}\text { Export, } \\
\text { domestic }\end{array}$ \\
\hline Free port & $\begin{array}{c}\text { Integrated } \\
\text { development }\end{array}$ & $>1000$ hectares & Multi-use & $\begin{array}{c}\text { Internal, } \\
\text { domestic \& export }\end{array}$ \\
\hline $\begin{array}{c}\text { Enterprise } \\
\text { zones }\end{array}$ & $\begin{array}{l}\text { Urban } \\
\text { revitalization }\end{array}$ & $<50$ hectares & $\begin{array}{l}\text { Manufacturing } \\
\text { and processing }\end{array}$ & Domestic \\
\hline $\begin{array}{l}\text { Single factory } \\
\text { EPZ }\end{array}$ & $\begin{array}{c}\text { Export \& } \\
\text { manufacturing }\end{array}$ & No minimum & $\begin{array}{l}\text { Manufacturing } \\
\text { and processing }\end{array}$ & Mostly export \\
\hline
\end{tabular}

Source: Derived from FIAS (2008) [4] and Farole (2011) [5]. 
individual enterprises regardless of location; factories do not have to locate within a designated zone to receive incentives and privileges. Enterprise zones are intended to revitalize distressed urban or rural areas through the provision of tax incentives and financial grants. Free port refers to a much larger area that accommodates all types of activities, including tourism and retail sales, permit on-site residence, and provide a broader set of incentives and benefits.

\subsection{Theoretical Review}

Since 1990s, the trend for liberalization, which has swept the developing world in the process of globalization and economic opening, has accelerated the establishment of free trade zones all over the world. Free trade zone can bring in economic effect and welfare effect by deregulation. However, the economic benefit is uncertain because of negative effects caused by trade distortion and improper supervisory measures. Hamada (1974) used the standard two-factor, two-commodity trade model to present a theoretical framework to analyze the economic implication of a duty-free zone, where duties are exempted in order to attract foreign investments [7]. Hamilton and Svensson (1983) analyzed the connection between foreign capital in host country and its free zone and summarized that with sector-specific capital, import of capital into the protected sector decreases welfare and vice versa. If capital import into the export sector of the domestic zone is infeasible, there may be a case for establishing a free zone to attract capitals exclusively there and with a suitable tax policy, capital import into the free zone will be beneficial [8]. Grubel (1983) in his book outlined the benefits and costs of regulation and proposed that "free economic zones can as both a substitute and complement to whatever deregulation or reform is achieved" [9]. He also indicated that the creation of free economic zones raises welfare through expansion of trade and specialization and affects the supply of work, technology and entrepreneurship. However, it also may reduce welfare through the locational diversion of trade and investment and the generation of negative externalities. Miyagiwa (1986) pointed that free trade zones are often established by government subsidies designed to promote non-traditional exports. He presented a model of a free-trade zone which the condition is derived under which the establishment of a free-trade zone can increase welfare regardless of the relative factor intensity of a zone-based industry and the relative factor intensity of a free-trade zone plays a crucial role in determining the change in welfare following economic growth and foreign investment [10].

Giovanni Facchini et al. (1999) used Dixit-Norman approach to investigate the gains from duty free zones and conclude that introduction of a duty free zone leads to Pareto gains over autarky and its welfare effect depends on the redistribution mechanism accompanying free trade [11].

Manash Ranjan Gupta (1994) considerred a small open Harris-Todaro economy with the urban sector consisting of a "duty-free zone" and a "non-duty free zone" and found that the expanding the duty-free zone policy by reducing import-duty 
on intermediate goods in that sector ultimately lowers the level of output of that sector, raises the level of unemployment, lowers national income (social welfare), and increases economic inequality. However, if the tariff on the final product is reduced in that sector, we get the opposite result [12].

Wei Ge (1995) analyzes direct and indirect impacts of urban enterprise zones on regional economies such as job creation, urban unemployment, agricultural wage and changes in the regional economic structure are analyzed by incorporating the intermediate goods sector. He suggests that the establishment of urban enterprise zones is a beneficial and effective policy instrument which can be used in promoting urban renewal and regional economic growth [13].

Peter G. Warr (1989) studies the benefits and costs of EPZS in Indonesia, the Republic of Korea, Malaysia, and the Philippines and reviews the relationship between the welfare effects of EPZS and the host country's economic policies and assumes that when the domestic economy is distorted, the EPZ confers limited welfare gains. Nevertheless, EPZS are far from the "engines of development" that some countries had initially hoped they would become [14].

Susan Tiefenbrun (2013) delves into the business benefits and tax advantages of FTZs in USA and abroad, suggests that FTZs can play a significant role in economic growth by increasing exports, enhancing industry competitiveness, and attracting foreign direct investment [15].

\subsection{Empirical Review}

Base on theoretical findings about the welfare effect and economic impacts of free trade zone, many researchers carried on empirical test to investigate the effect of free trade zone in different economies. Rong Her Chiu et al. (2011) employ importance performance analysis (IPA) technique to analyze the performance of MNCs operating in FTPZs in Taiwan. Five factors, including government administration efficiency, cheap rates and charges, simplified customs procedures, clear regulations, and free tax incentives, were found to have important impacts on business operations in FTPZs. Further, results indicated that firms in FTPZ had increased their performance in terms of reputation, investment, customer satisfaction, and revenue [16].

Chee Kian Leong (2013) carries out an empirical investigation on special economic zones and growth in China and India. He supposes the presence of SEZs increases regional growth but increasing the number of SEZs has negligible effect on growth and the greater pace of liberalization appears to be the key to faster economic growth [17].

Aradhna Aggarwal (2005) applied a comparative analysis about the performance of export processing zones in India, Sri Lanka and Bangladesh. The empirical analysis reveals that the relative advantages, for examples: incentives, infrastructure and governance, enjoyed by the EPZ units vis-à-vis the rest of the economy attract investment in the zones while overall governance and infrastructure facilities in a country determine the export competitiveness of its 
zones [18].

Kankesu Jayanthakumaran (2003) uses a benefit-cost analytical framework to survey the performance of Export Processing Zones, suggest that zones in South Korea, Malaysia, Sri Lanka, China and Indonesia are economically efficient and generate returns well above estimated opportunity costs. In addition, the zones have been an important source of employment in all cases and have promoted local entrepreneurs in some. However, as industrial development proceeds, the gap between the market and opportunity costs of labor narrows and the interest in EPZs tends to disappear. It may hold only if the zones generate private profit to domestic shareholders [19].

MENG Guangwen, LIU Ming (2011) applied fuzzy synthetic evaluation method, analytic hierarchy process (AHP) and questionnaire to build an evaluation model with a three-level index system according to free trade theory and empirical experience of world free trade zones and free ports. The study evaluates the comprehensive development level of Tianjin Binhai New Area's three bonded zones in terms of the objective and its utility, freedom and openness, functional development as well as environment improvement [20].

Based upon previous researches' result, special economic zone, particularly FTZ is expected to bring about economic gain to the region and the enterprises operating in the zone. However, in some special cases, the policy's effect is negligible or even counteractive with the expectation. Most empirical researches carried out the analysis by a factor evaluation model approach which is needed to predefine effected factors and processed with actual data. Therefore, it requires sufficient source of data to guarantee the reliability of results and avoid spurious regression. In this paper, we use a counter-factual method to investigate the effect of the Shanghai Pilot Free Zone. Counter-factual model that designs a counter-factual scenario to compare with practical situation is suitable for the new-established zone in consideration of data shortage. By applying counter-factual method, the paper also quantifies the policy's effect of Shanghai FTZ on its economic growth that is difficult to obtain by using different methods. Hence, it is supposed to give a more convincing and specific view of Shanghai FTZ and its contribution to economic growth and liberalization.

\section{Economic and Political Reform behind Shanghai Pilot Free Trade Zone}

The construction and management of Shanghai FTZ are stipulated in the government documents namely "the Measures for Administration of the China (Shanghai) Pilot Free Trade Zone" ("The Measure" in short) released on September 27th 2013. Comprehensively, its economic and political reform falls into five aspects: institutional innovation, service industry opening-up deepening, trade facilitation, financial deregulation and legislation and political guarantee.

\subsection{Institutional Innovation}

One of the important role of Shanghai pilot FTZ is an experiment plot for the 
transformation of government functions in China. Learning from generally accepted international rules, Shanghai FTZ provided new measures in terms of foreign investment management, such as offering pre-access national treatment and implementing Negative List management mode for foreign investment; in term of industrial and commercial registration administration, such as adopting the filling registration system for foreign investment projects and enterprises with single-window working mechanism access. The filing procedure is also applied for overseas investment projects and overseas investment in enterprise operating inside the Zone. The institutional innovation of the Zone is expected to promote investment facilitation, create more cooperation and investment opportunities for foreign investors and deepen the liberalization of Shanghai FTZ.

\subsection{Deepening the Opening-Up of Service Industry}

The FTZ deepened the opening-up level in 6 fields covering 18 industries: financial services; shipping services; commercial and trade services; professional services; cultural services; social services. The main measures include suspension or cancelation the investors' qualifications, restrictions on shareholding proportions, scope of business and other access restrictions, with a total of 23 measures, of which, 5 items in financial area, 3 items in shipping area, 2 items in business area, 8 items in professional services, 2 items in trade area and 3 items in social service area. For the first time, it is proposed to set up a limited license bank in the trade area, to set up a professional health medical insurance institution, to open financial leasing company, to run a commercial insurance business related to its main business, and to operate foreign-owned international shipping enterprises inside the Zone.

\subsection{Trade Facilitation}

The innovation in customs supervision system was conducted in the Shanghai FTZ to develop the new trade business mode, according to the principles of "opening at front-line, exercising efficient control over the back-line, and free circulation within the zone", of which "front-line" refers to the administration between the PFTZ and overseas is, and back-line refers to the administration between the PFTZ and the place inside the border and outside the zone. A single-window comprehensive management service platform for trans-department trade, transportation, processing, storage and other business in the zone was also set up in the zone to facilitate international trade operation. Simultaneously, Shanghai FTZ supports the transformation and upgrading of basic businesses of international trade, storage and logistics, processing manufacture and the development of service trade. Regarding to trade form, the development of offshore trade, entrepot trade, financing lease, bonded delivery of futures, trans-border e-commerce and other new trade, outsourcing businesses such as biomedical $\mathrm{R} \& \mathrm{D}$, software and information service and data processing are Shanghai FTZ new development key points in future. The new trade mode may bring about 
favorable economic growth, but it also has risk potential. For example, International floating capital from offshore trade may strike one country's financial system. Therefore, the details of the Measure need to be carefully designed and optimized in ordered to avoid the risk in future.

\subsection{Financial Deregulation}

The Measures put forward the deepening opening-up and innovation in the financial field through following four measures: Implementing capital account convertibility together with creating new business and management mode under proper risk control through separate accounting; establishing an independent pricing mechanism of financial institutions in conformity with real economic development and an interest-rate market-driven system will gradually be promoted; encouraging and supporting the expanded RMB cross-border use apply to the PFTZ pursuant to enterprises own operational needs; establishing a foreign exchange administrative mechanism in line with the development demands of the FTZ, so as to facilitate trade and investment.

Besides, the Municipality, in cooperation with the financial administration, tend to establish a risk prevention mechanism in accordance to the financial business development in the Zone.

\subsection{Accelerating Legislation and Political Guarantee}

The Shanghai FTZ provides the State legal guarantee with 5 related special investment laws and administrative regulations as well as FTZ-specialized supporting documents from 12 ministries. On the area level, Shanghai Municipal Government has formulated and promulgated related policies to strengthen local legislation system, such as Administrative Measures for the Access of Foreign Investment in China (Shanghai) Pilot Free Trade Zone (Negative List) (2013), the Measures for Administration of the Filing of Foreign Investment Projects in the China (Shanghai) Pilot Free Trade Zone in 2013 and the Measures for Administration of the Filing of Foreign-Invested Enterprises in China (Shanghai) Pilot Free Trade Zone (2013). In the Zone, the equal positions and rights to development of various market subjects, the enterprise, equity, intellectual property right, profit and other property and business interests of investors, the rights of workers etc. are protected by law.

Overall, the key points in reform of Shanghai FTZ are different from and prior to the traditional special economic zone. It is the special experimental field designated to promote the economic reform and liberalization, to deepen the comprehensive innovation of China in new era.

\section{Empirical Analysis}

\subsection{Counter-Factual Model in a Panel Data Framework}

In order to examine the effect of exogenous intervention on individual, natural science research often randomly choose two groups of examples from the popu- 
lation, implement intervention on the first group (so-called experimental group) and keep the second group unchanged (so-called control group) then compare the value of two groups. The difference between two groups, or the so-called treatment effect, is used to measure the effect of exogenous intervention. However, in empirical research, it is difficult to implement random experiment, so the "counter-factual analysis" was developed on the basis of this idea to solve the question: "If the intervention didn't exist, what would be the outcome of observed variables?" Later on, the counterfactual analysis method has been used widely in any research fields. Counterfactuals are posed by "what if" questions, such as "what would the U.S. economy have been like in 1890 had there been no railroads?" [21]. In economics, counterfactuals are considered in decision making under uncertainty to evaluate policy's effects [22]. For examples, Hsiao et al (2012) use counterfactual method to analyze the effect of political and economic integration with mainland China on growth in Hong Kong [23]. Angrist et al. (2011) explain the effect of monetary shocks in the US by using counterfactual analysis [24]. Orphanides and Williams (2011) used the method to answer the question "what would have been the effect of the Federal Reserve following a different policy rule?" [25]

The panel data framework for constructing counterfactual is based on the correlation among cross-sectional unit. We assume there are $n$ units observed over time period $T$, denote $y_{i t}$ the outcome of the $i^{\text {th }}$ observed unit at time $t$. The objective is to measure the average effect of the policy intervention on $y_{i t}$ The intervention is such that the "policy on" realized values of the policy variable are different from the "policy off" counterfactual which would have happened in the absence of the intervention. We assume the correlations among cross-sectional units are driven by some common factors, although their impacts on each cross-sectional unit may be different. Denote $y_{i t}^{0}$ is the outcome of $y_{i}$ at time $\mathrm{t}$ without policy intervention, $y_{i t}^{0}$ can be generated by a factor model (Forni and Reichlin, 1998) (Gregory and Head, 1999):

$$
y_{i t}^{0}=a_{i} f_{t}+b_{i}+e_{i t}
$$

where $f_{t}$ denotes $k \times 1$ vector of common factors that differs over time, $a_{i}$ denotes $1 \times k$ vector of coefficient that varies from different units, $b_{i}$ denotes the fixed individual-specific effects, $e_{i t}$ denotes the $i^{\text {th }}$ unit random error with $E\left(e_{i t}\right)=$ 0 . The equation 3.1 is rewritten in vector form as follow:

$$
Y_{t}^{0}=A F_{t}+B+E_{t}
$$

where $Y_{t}^{0}$ is the $n \times t$ factors loading outcome matrix $Y_{t}^{0}=\left(y_{1 t}^{0}, y_{2 t}^{0}, \cdots, y_{n t}^{0}\right)^{\prime} ; A$ is the $n \times k$ factors loading coefficient matrix $A=\left(a_{1}, a_{2}, \cdots, a_{n}\right)^{\prime} ; F_{t}$ is the $k \times t$ factors loading control factor matrix $F_{t}=\left(f_{1}, f_{2}, \cdots, f_{k}\right)^{\prime} ; B$ is the $n \times t$ fixed individual-specific effects matrix $B=\left(b_{1}, b_{2}, \cdots, b_{n}\right)$ and $E_{t}$ is the $n \times t$ random error matrix $E_{t}=\left(e_{1 t}, e_{2 t}, \cdots, e_{n t}\right)^{\prime}$.

Denote $Y_{1 t}^{1}$ the outcome of $Y_{i}$ at time $t$ under policy intervention. Then the treatment effect for $Y_{i}$ at time $t$ is: 


$$
\Delta_{i t}=y_{i t}^{1}-y_{i t}^{0}
$$

However, $y_{i t}^{1}$ and $y_{i t}^{0}$ cannot be observed at the same time. Suppose that a policy intervention is announced at the end of period $t$ for the periods $t+1, t+2, \cdots, T$. Let denote $d$ the dummy variable of policy intervention, where

$$
d_{t}=\{1 \mid(t+1, t+2, \cdots, T)\} ; d_{t}=\{0 \mid(1,2, \cdots, t)\}
$$

Then $y$ is written

$$
y_{i t}=d_{i t} y_{i t}^{1}+\left(1-d_{i t}\right) y_{i t}^{0}
$$

At time $t+1$, policy intervention has effect on the $t^{\text {th }}$ unit, without loss of generality, we assume the first unit has received the treatment while other units haven't been affected by policy intervention. Then:

$$
\begin{gathered}
y_{1 t}=y_{i t}^{0} \quad \text { for } t=1,2, \cdots, t \\
y_{1 t}=y_{i t}^{1} \quad \text { for } t=t+1, t+2, \cdots, T \\
y_{i t}=y_{i t}^{0} \text { for } i=2,3, \cdots, n \text { and } t=1,2, \cdots, T
\end{gathered}
$$

The policy effect on $y_{1}$ is generated as follow:

$$
\Delta_{1 t}=y_{1 t}^{1}-y_{1 t}^{0}
$$

for $t=t+1, t+2, \cdots, T$.

We can only observe $y_{1 t}^{1}$ at time period $t+1, t+2, \cdots, T$ and need to predict the counterfactual value $y_{1 t}^{0}$. Because the observed units are limited and time period $\mathrm{t}$ is not large, it is suggested to use $\hat{y}=\left(y_{2 t}, \cdots, y_{n t}\right)^{\prime}$ in lieu of $f_{t}$ to predict $y_{1 t}^{0} \quad$ [23]. Denote $y_{1 t}^{\prime 0}$ the estimated counterfactual value of $y_{1 t}^{0}$,

Suppose that $\bar{a}=\left(\bar{a}_{1}, \bar{a}_{2}, \cdots, \bar{a}_{k}\right)$, with $\bar{a}_{1} \neq 0$ is the $k \times 1$ vector that $A \bar{a}=0$ then $\bar{a}=N(A)$, while $N(A)$ represents the null space of matrix $A$. Then:

$$
\bar{a}=\left(\bar{a}_{1}, \bar{a}_{2}, \cdots, \bar{a}_{k}\right)=\bar{a}_{1}\left(1, \bar{a}_{2} / \bar{a}_{1}, \cdots, \bar{a}_{k} / \bar{a}_{1}\right)=\bar{a}_{1} \bar{a}^{\prime}=\bar{a}_{1}(1, \hat{a})
$$

The coefficient matrix is rewritten $A=\left(a_{1}, a_{2}, \cdots, a_{n}\right)^{\prime}=\left(a_{1}, \hat{A}\right)^{\prime}$

Easily to yield: $A \bar{a}_{1} \vec{a}=\bar{a}_{1} A \vec{a}=0$ then $A \vec{a}=0$

Denote $Y_{t}^{0}=\left(y_{1 t}^{0}, \ddot{Y}_{t}^{0}\right)^{\prime}$ while $\ddot{Y}_{t}^{0}=\left(y_{2 t}^{0}, \cdots, y_{n t}^{0}\right)^{\prime} ; \quad E_{t}=\left(e_{1 t}, \hat{E}_{t}\right)^{\prime}$ while $\hat{E}_{t}=\left(e_{2 t}, \cdots, e_{n t}\right)^{\prime}$. Multiple two sides of Equation (4.2) by $\vec{a}^{\prime}$ then:

$$
\begin{gathered}
(1, \hat{a})\left(y_{1 t}^{0}, \ddot{Y}_{t}^{0}\right)^{\prime}=\vec{a} A F_{t}+\bar{a}^{\prime} B+(1, \hat{a})\left(e_{1 t}, \hat{E}_{t}\right)^{\prime} \\
\text { then } y_{1 t}^{0}+\hat{a} \ddot{Y}_{t}^{0}=\left(\vec{a}^{\prime} A\right) F_{t}+\vec{a}^{\prime} B+e_{1 t}+\hat{a} \hat{E}_{t} \\
\text { yields: } y_{1 t}^{0}=-\hat{a} \ddot{Y}_{t}^{0}+\bar{a}^{\prime} B+e_{1 t}+\hat{a} \hat{E}_{t} \\
\text { Denote }-\hat{a}=\alpha ; \quad \bar{a}^{\prime} B=\beta ; \quad e_{1 t}+\hat{a} \hat{E}_{t}=\varepsilon_{t} ; \text { therefore: } \\
y_{1 t}^{0}=\alpha \ddot{Y}_{t}^{0}+\beta B+\varepsilon_{t}
\end{gathered}
$$

The Equation (4.9) indicates that $y_{1 t}^{0}$ can be predicted by using $\ddot{Y}_{t}^{0}$ instead of $f_{t}$. It is said that if $t$ is limited then "there may be an advantage to use only a subset of available cross-sectional units to predict the counterfactual" [23].

Let $y_{1 t}^{\prime 0}$ be estimated value of $y_{1 t}^{0}$, the estimated policy effect on $y_{1}$ is calculated by: 


$$
\Delta_{1 t}^{\prime}=y_{1 t}^{1}-y_{1 t}^{\prime 0} .
$$

If $\Delta_{1 t}^{\prime}$ time series is stationary, then the long-term treatment effect can be calculated as follow:

$$
\Delta_{1}=\frac{1}{T-t} \sum_{t=t+1}^{T} \Delta_{1 t}^{\prime}
$$

\subsection{Data Resource and Modeling}

In this paper, the counterfactual analysis is applied to analyze the effects of Shanghai FTZ on its economic over two periods of time: from 2005 to 2013 when FTZ hasn't been established and from Sep, 2013 to 2017 when SHFTZ has been established. This paper aims to analyze the policy effect of Shanghai Pilot Free Trade Zone on its local economic growth. The economic growth is represented by provincial GDP. The paper used the dataset of 31 provinces in China from the first quarter of 2005 to the first quarter of 2017, of which the period from the first quarter of 2005 to the third quarter of 2013 before Shanghai FTZ was established is considered the "policy-off" and the period from the fourth quarter of 2013 to the first quarter of 2017 after Shanghai FTZ was established is considered the "policy-on". All the data is derived from The National Bureau of Statistics of China, computing in one hundred million RMB (One hundred million is Chinese measurement unit, called Yi). Because original GDP value is in accumulated form so we need to transfer into current value by following equation:

$$
X_{j i}= \begin{cases}G D P_{j i}, & i=1 \\ G D P_{j i}-X_{i-1}, & i=2,3,4\end{cases}
$$

where $X_{j i}$ denotes the $i^{\text {th }}$ quarter current GDP value of province $j$.

It is also noted that the four quarters within one year have different numbers of working days and the GDP is affected by seasonal effects. This paper processed $\mathrm{X}-12$ seasonal adjustment method to remove seasonality and calendar effect on time series.

In order to select the variables subset, there are many methods were introduced in previous researches, such as Hierarchical Models [26], Penalized regression methods, including the Lasso regression [27], Akaike's information technique or stepwise regression model [28] [29]... This paper applied stepwise regression method to select predictors. Stepwise regression is deemed to evaluate the order of importance of variables and to select useful subsets of variables [30] [31]. Stepwise regression begins with no variables in the model, predictor variables are entered into the regression equation one at a time based upon statistical criteria. At each step of the analysis, the predictor variable that contributes the most to the prediction equation in terms of increasing the multiple correlation, $\mathrm{R}$, is entered first. Then all entered predictors are checked to see their significance in subsequent steps. If they no longer contribute appreciable unique predictive power to the regression when considered in combination with newly 
entered predictors, they will be removed from the model [31]. This process stops only if all variables added are significant.

\section{Empirical Result and Policy Effect Analysis}

\subsection{Results}

By applying SPSS software to carry out stepwise regression on the 30 predictors, we selected two variables to predict the GDP of Shanghai, including Neimenggu and Zhongqing. The linear regression model is expressed in Equation (5.1) with high fitting optimization index $\mathrm{R}=0.996$ and $\mathrm{F}$ value $=1811.248$ significant at $5 \%$ level.

$$
\text { XShanghai }=1556.386+1.226 * \text { XNeimenggu }-0.454 * \text { XZhongqing }
$$

The actual and counter-factual GDP of Shanghai is shown in Table 3. The result implies positive effect of Free Trade Zone on Shanghai GDP (Figure 1) and it is playing more and more important role to enlarge Shanghai GDP (Figure 2). At the first quarter after FTZ established, the effect of FTZ on Shanghai economic is small, accounting only $5.68 \%$. At the end of 2014 , it is believed to make 13.2\% contribution to Shanghai GDP. In 2015 and in 2016, the average effect of Shanghai FTZ on it economic growth increased to $15.2 \%$ and 22.9 respectively. The results lead to a matter of fact that the pilot zone is playing more and more important role in accelerating the area's economic growth in accordance to its strategy's maturity. Hence, the Shanghai Municipal should continuously focus on the policy's reform, deepen its policy reform and government function transformation, makes more transparent administration procedure in order to

Table 3. Treatment effect of SHFTZ on Shanghai GDP.

\begin{tabular}{ccccc}
\hline Period & Shanghai Real GDP & $\begin{array}{c}\text { Shanghai counter-factual } \\
\text { GDP }\end{array}$ & $\begin{array}{c}\text { Treatment effect } \\
\Delta_{\text {lt }}\end{array}$ & Change in \% \\
\hline 2013Q4 & 5502 & 5189.464 & 312.536 & 5.68040712 \\
2014Q1 & 5631 & 5356.688 & 274.312 & 4.87146155 \\
$2014 \mathrm{Q} 2$ & 5714 & 5280.414 & 433.586 & 7.58813441 \\
$2014 \mathrm{Q} 3$ & 5924 & 5420.884 & 503.116 & 8.49284267 \\
$2014 \mathrm{Q} 4$ & 6236 & 5413.688 & 822.312 & 13.1865298 \\
$2015 \mathrm{Q} 1$ & 6154 & 5317.438 & 836.562 & 13.5937927 \\
$2015 \mathrm{Q} 2$ & 6165 & 5099.41 & 1065.59 & 17.2845093 \\
2015Q3 & 6265 & 5307.438 & 957.562 & 15.2843097 \\
2015Q4 & 6363 & 5429.88 & 933.12 & 14.6647808 \\
$2016 \mathrm{Q} 1$ & 6581 & 5393.398 & 1187.602 & 18.0459201 \\
2016Q2 & 6842 & 4909.72 & 1932.28 & 28.2414499 \\
2016Q3 & 6891 & 5592.588 & 1298.412 & 18.8421419 \\
2016Q4 & 7109 & 5216.776 & 1892.224 & 26.617302 \\
2017Q1 & 7318 & 5493.838 & 1824.162 & 24.9270566 \\
\hline
\end{tabular}




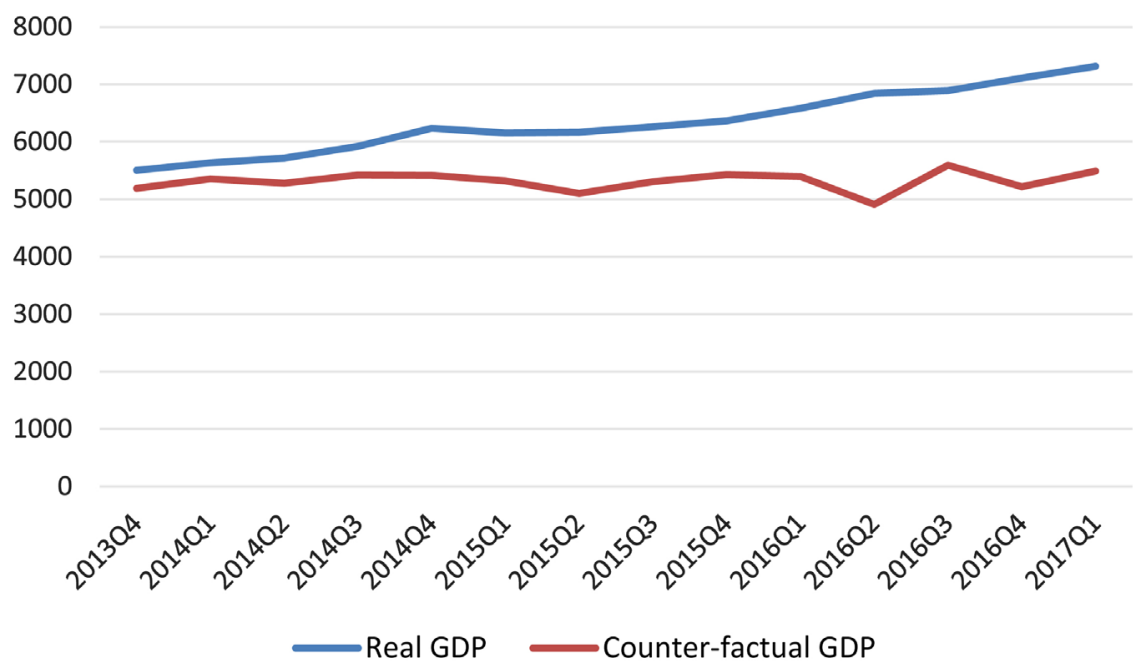

Figure 1. Comparison between real GDP and Counter-factual GDP of Shanghai after establishing FTZ.

\section{Change of GDP in \%}

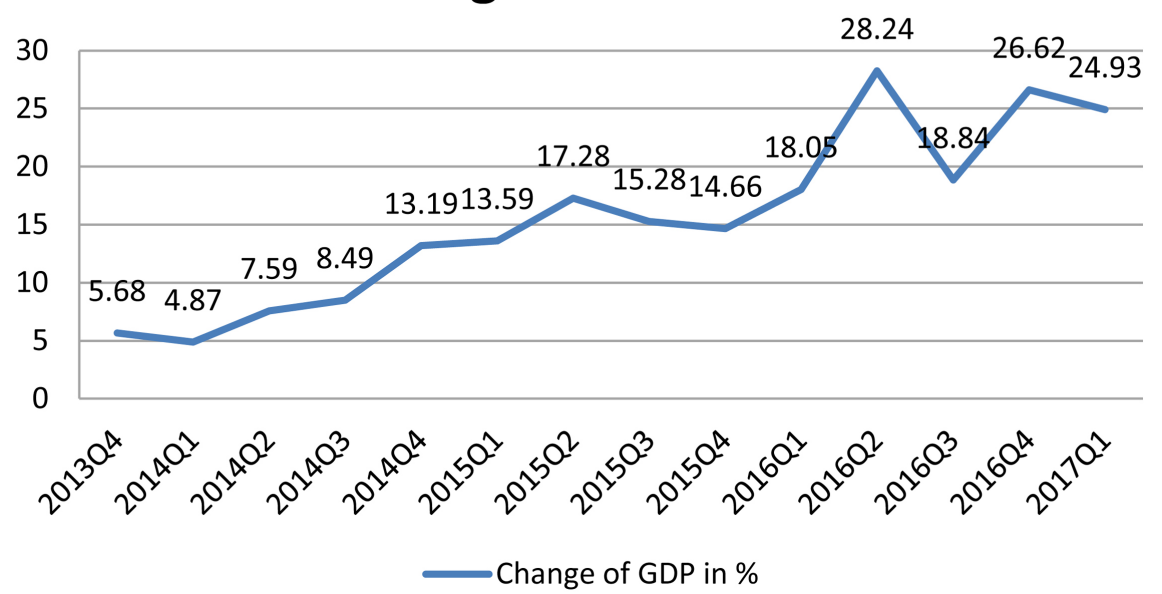

Figure 2. The policy effect of SHFTZ on Shanghai GDP.

facilitate trading and financing as well as attract more foreign investment. On other hand, with the positive effect was concluded above, the other provinces, especially the other new free trade zone in China should learn the successful experiences of Shanghai pilot free zone, exclude the shortages to avoid detours in the process of establishing free trade zone adapting to its own characteristic and priority.

\subsection{Model Robustness Test}

In order to test the robustness for predictor variables of the research, we suppose that the Shanghai FTZ was established one year earlier, in September of 2012. Then we adopt the same method to select the predictor variables for counter-factual value and see if there is any change in the finding. The stepwise regression is applying again on 30 predictors from 2005 to 2012-Q2 to select the 
fittest variables and prediction equation for Shanghai in the case of Shanghai FTZ being established one year forward. In this case, Neimenggu and Zhongqing are still chosen as best-fitting combination of variables. Shanghai GDP is predicted in Equation (5.2):

$$
\text { XShanghai }=1570.084+1.221 * \text { XNeimenggu }-0.458 * \text { XZhongqing }
$$

Figure 3 shows the difference between the real value and the counter-factual GDP of Shanghai in the period from 2012-Q4 to 2017-Q1. From 2012-Q4 to 2013-Q3 when Shanghai FTZ hasn't been established, the real value line is close to the counter-factual regression line, implies that in reality, without policy intervention, Shanghai GDP can be well-predicted by Neimengu and Zhongqing. Since 2013-Q4, after the FTZ has been created, the real value line starts moving upward and lies upon counter-factual regression line, implies that the FTZ has significant and increasing effect on Shanghai economic growth. This finding confirms the results concluded in last section.

\section{Conclusions}

The paper uses macro counterfactual method to analyze the effects of free trade zone on Shanghai economic growth. In this paper, Neimenggu and Zhongqing were chosen by a stepwise regression in lieu of common factors in order to predict Shanghai's pre-treatment value. By comparing the counter-factual value and factual value of variable, this paper concludes a strong treatment effect of Shanghai FTZ on its economic growth. The result was affirmed by model robustness test that emphasized the treatment effect is significant only after the Shanghai FTZ was practically created. By using a new analyzing method, this paper provides a quantitative and crucial evidence of Shanghai FTZ influence on its economic growth. The finding implies the accurate strategy of Chinese government in term of economic reform toward liberalization and other new free trade zone that was recently approved should learn experience from the Shanghai pilot free trade zone in order to further up its economic reform successfully.

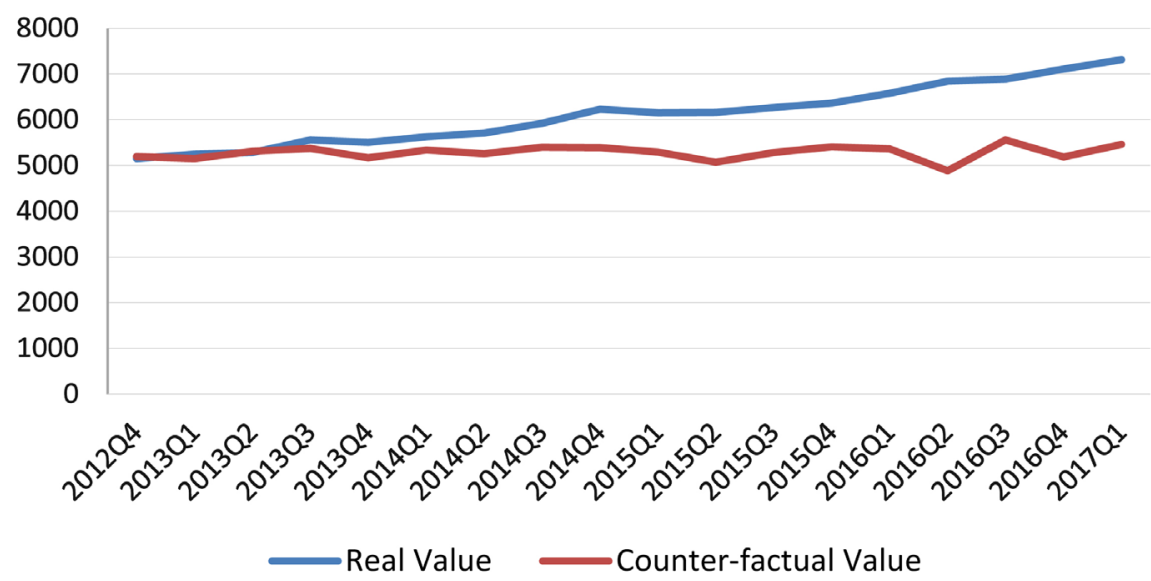

Figure 3. Comparison between real GDP and Counter-factual GDP of Shanghai from 2012-Q4 to 2017Q1. 


\subsection{Limitations of This Research}

During conducting this research, we could access the quarterly data of 31 provinces in China since 2005. If we could access the earlier data, more authentic scenario could be explored. This paper used stepwise method to select predictor variables for counter-factual model, and the results concluded may differ from other methods.

\subsection{Further Research Directions}

In this study, the empirical test is only applied for provincial GDP to examine the policy's effect of Shanghai pilot free trade zone but the application of the research can be enlarged to different industries and indexes such as: import, export, services... etc. We also can use this model to investigate the policy's effects of different policy in different provinces.

\section{Acknowledgements}

The authors would like to express sincere gratitude to the Institute of Industrial Economics of Hohai University for all kind of institutional support during this research.

\section{References}

[1] China Shanghai Pilot Free Trade Zone. http://en.china-shftz.gov.cn/

[2] China Announces Plans for Pilot Free Trade Zones. 2015. http://english.mofcom.gov.cn/

[3] Xinhua: Gao Hucheng: Seven Free Trade Pilot Sites Are Newly Established and Beginning A New Voyage of Pilot Exploration. 2016. http://english.mofcom.gov.cn/

[4] FIAS (2008) Special Economic Zones: Performance, Lessons Learned, and Implications for Zone Development. The World Bank, Washington DC, E3.

[5] Farole, T. and Akinci, G. (2011) Special Economic Zones: Progress, Emerging Challenges, and Future Directions. World Bank Publications. https://doi.org/10.1596/978-0-8213-8763-4

[6] Grubel, H.G. (1982) Towards a Theory of Free Economic Zones. Review of World Economics, 118, 39-61. https://doi.org/10.1007/BF02706078

[7] Hamada, K. (1974) An Economic Analysis of the Duty-Free Zone. Journal of International Economics, 4, 225-241. https://doi.org/10.1016/0022-1996(74)90044-0

[8] Hamilton, C. and Svensson, L.E. (1983) On the Choice between Capital Import and Labor Export. European Economic Review, 20, 167-192. https://doi.org/10.1016/0014-2921(83)90062-4

[9] Grubel, H.G. (1983) Free Market Zones: Deregulating Canadian Enterprise. Fraser Institute, Vancouver.

[10] Miyagiwa, K.F. (1986) A Reconsideration of the Welfare Economics of a Free-Trade Zone. Journal of International Economics, 21, 337-350. https://doi.org/10.1016/0022-1996(86)90045-0

[11] Facchini, G. and Willmann, G. (1999) The Gains from Duty Free Zones. Journal of International Economics, 49, 403-412. 
[12] Gupta, M.R. (1994) Foreign Capital, Income Inequality and Welfare in a Harris-Todaro Model. Journal of Development Economics, 45, 407-414.

[13] Ge, W. (1995) The Urban Enterprise Zone. Journal of Regional Science, 35, 217-231. https://doi.org/10.1111/j.1467-9787.1995.tb01255.x

[14] Warr, P.G. (1989) Export Processing Zones: The Economics of Enclave Manufacturing. The World Bank Research Observer, 4, 65-88.

https://doi.org/10.1093/wbro/4.1.65

[15] Tiefenbrun, S. (2013) US Foreign Trade Zones, Tax-Free Trade Zones of the World, and Their Impact on the US Economy.

[16] Chiu, R.-H., et al. (2011) An Evaluation of Free Trade Port Zone in Taiwan. The Asian Journal of Shipping and Logistics, 27, 423-445.

[17] Leong, C.K. (2013) Special Economic Zones and Growth in China and India: An Empirical Investigation. International Economics and Economic Policy, 10, 549-567. https://doi.org/10.1007/s10368-012-0223-6

[18] Aggarwal, A. (2005) Performance of Export Processing Zones: A Comparative Analysis of India, Sri Lanka and Bangladesh. Indian Council for Research on International Economic Relations, 155, 10-13.

[19] Jayanthakumaran, K. (2003) Benefit-Cost Appraisals of Export Processing Zones: A Survey of the Literature. Development Policy Review, 21, 51-65. https://doi.org/10.1111/1467-7679.00198

[20] Meng, G. and Liu, M. (2011) Evaluation on the Establishment of Free Trade Zones in Tianjin Binhai New Area. Acta Geographica Sinica, 2, 10.

[21] Fogel, R.W. (1994) Railroads and American Economic Growth. Books on Demand.

[22] Heckman, J.J. (2008) Econometric Causality. International Statistical Review, 76, 1-27. https://doi.org/10.1111/j.1751-5823.2007.00024.x

[23] Hsiao, C., Ching, H.S. and Wan, S.K. (2012) A Panel Data Approach for Program Evaluation: Measuring the Benefits of Political and Economic Integration of Hong Kong with Mainland China. Journal of Applied Econometrics, 27,705-740. https://doi.org/10.1002/jae.1230

[24] Angrist, J.D. and Kuersteiner, G.M. (2011) Causal Effects of Monetary Shocks: Semiparametric Conditional Independence Tests with a Multinomial Propensity Score. Review of Economics and Statistics, 93, 725-747. https://doi.org/10.1162/REST_a_00109

[25] Orphanides, A. and Williams, J. (2011) Monetary Policy Mistakes and the Evolution of Inflation Expectations. National Bureau of Economic Research. https://doi.org/10.3386/w17080

[26] Gelman, A. and Hill, J. (2007) Data Analysis Using Regression and Multilevel/Hierarchical Models. Vol. 45, Cambridge University, New York.

[27] Tibshirani, R. (1996) Regression Shrinkage and Selection via the Lasso. Journal of the Royal Statistical Society. Series B (Methodological): 267-288.

[28] Ma, E. (1960) Multiple Regression Analysis. In: Ralston, A. and Wilf, H., Eds., Mathematical Methods for Digital Computers, Vol. 1, John Wiley \& Sons, New York.

[29] Walter, S. and Tiemeier, H. (2009) Variable Selection: Current Practice in Epidemiological Studies. European Journal of Epidemiology, 24, 733.

[30] Huberty, C.J. and Morris, J.D. (1989) Multivariate Analysis versus Multiple Univariate Analyses. Psychological Bulletin, 105, 302. 
https://doi.org/10.1037/0033-2909.105.2.302

[31] Thompson, B. (1995) Stepwise Regression and Stepwise Discriminant Analysis need Not Apply Here: A Guidelines Editorial. Sage Publications, Thousand Oaks.

Submit or recommend next manuscript to SCIRP and we will provide best service for you:

Accepting pre-submission inquiries through Email, Facebook, LinkedIn, Twitter, etc. A wide selection of journals (inclusive of 9 subjects, more than 200 journals) Providing 24-hour high-quality service User-friendly online submission system Fair and swift peer-review system Efficient typesetting and proofreading procedure Display of the result of downloads and visits, as well as the number of cited articles Maximum dissemination of your research work

Submit your manuscript at: http://papersubmission.scirp.org/

Or contact jss@scirp.org 